\title{
PENGARUH METODE PROBLEM SOLVING DAN KOOPERATIF TIPE THINK PAIR SHARE TERHADAP PRESTASI BELAJAR IPS DI SEKOLAH DASAR ISLAM TERPADU
}

\author{
Asep Kurniawan \\ Institut Agama Islam Negeri Syekh Nurjati Cirebon \\ asepkurniawan@syekhnurjati.ac.id
}

\begin{abstract}
ABSTRAK
Tujuan penelitian adalah untuk mengungkap sejauhmana pengaruh metode problem solving dan kooperatif tipe think pair share terhadap prestasi belajar ilmu pengetahuan sosial di sekolah dasar Islam terpadu Sabilul Huda Cirebon. Jenis penelitian ini ialah penelitian kuantitatif, pendekatan penelitian ini assosiatif. Populasi dalam penelitian ini ialah 350 peserta didik kelas VI di SDIT Sabilul Huda Cirebon, teknik samplingnya ialah Cluster sampling. Sampel dalam penelitian ini ialah 77 peserta didik di SDIT Sabilul Huda Cirebon. Hasil penelitiannya ialah (1) Metode pembelajaran problem solving mata pelajaran IPS mendapatkan kecenderungan $66 \%$ atau 51 responden mempunyai metode pembelajaran problem solving dengan katagori sangat baik. Pembelajaran kooperatif tipe Think Pair Share mata pelajaran IPS mendapatkan kecenderungan 61\% atau 47 responden mempunyai pembelajaran kooperatif tipe Think Pair Share dengan katagori sangat baik. (2) Ada pengaruh yang signifikan pengaruh metode pembelajaran problem solving terhadap prestasi belajar IPS di SDIT Sabilul Huda. (3) Pembelajaran kooperatif tipe Think Pair Share ialah memiliki pengaruh lebih besar dari pada metode pembelajaran problem solving terhadap prestasi belajar IPS di SDIT Sabilul Huda.
\end{abstract}

Kata Kunci: kreatifitas, guru, efektifitas, berfikir kritis

\section{ABSTRACT}

The purpose of the research was to reveal the extent of the effect of problem solving methods and cooperative types of think pair share on social science learning achievements in Islamic elementary full day school Sabilul Huda Cirebon. The research was quantitative research with an associative approach. The population in this study was 350 students of class VI. The sampling technique was cluster sampling, i.e. 77 students. The results of his research were (1) problem solving learning methods in social studies get a tendency of $66 \%$ or 51 respondents who used problem solving learning methods with very good categories. Think Pair Share Cooperative learning of social studies, respondents got a tendency of $61 \%$ or 47 respondents used cooperative learning of Think Pair Share had a very good category. (2) There was a significant influence of the problem solving learning method on social studies learning achievement in Islamic elementary full day school Sabilul Huda. (3) Cooperative learning of Think Pair Share had a greater influence than the problem solving learning 
method on social studies learning achievement in Islamic elementary full day school Sabilul Huda.

Keywords: creativity, teacher, effectiveness, critical thinking

\section{A. PENDAHULUAN}

Proses pendidikan juga jelas berhubungan dengan setiap usaha yang mesti dilaksanakan untuk peningkatan Sumber Daya Manusia (Asaju, Anyio, Kajang, 2013: 1-7). Pendidikan adalah suatu proses yang kompleks, mencakup banyak komponen yang berhubungan satu sama lain. Apabila pendidikan ingin diwujudkan secara teratur dan terencana, maka berbagai komponen sistem pendidikan secara bersama diperhatikan (Fatah, 2004: 6).

Guru merupakan salah satu komponen sistem pendidikan yang bertanggungjawab terhadap perkembangan dan pendidikan para siswanya. Dia adalah aktor penting dan penentu keberhasilan program dan mutu pendidikan dan sumber daya manusia yang sangat erat kaitannya dengan siswa dalam proses pendidikan di sekolah (Fredriksson. 2014: 2-3).

Pendidikan dikatagorikan berkualitas jika proses pembelajarannya berjalan dengan efektif, siswa mendapatkan pengalaman yang bermakna bagi dirinya, dan produk pendidikan adalah manusia yang berguna bagi masyarakat dan pembangunan bangsa. Disamping itu siswa berbeda dalam banyak hal, khususnya intelegensinya. Intelegensi ialah totalitas kemampuan individu untuk berfikir, bertindak dengan terarah, mengolah dan menguasai lingkungan dengan efektif. Banyak peserta didik yang prestasi belajarnya kurang baik. Hal ini dapat diatasi dengan pengunaan metode pembelajaran yang tepat, diantaranya adalah metode problem solving dan kooperatif Tipe Think Phair Share.

Metode Pembelajaran problem solving (pemecahan masalah) digunakan dalam aktivitas pembelajaran dengan maksud untuk melatih dan membiasakan peserta didik menghadapi banyak permasalahan, baik itu persoalan pribadi ataupun persoalan kelompok untuk dipecahkan sendiri atau dengan orang lain. Pembelajarannya difokuskan kepada investigasi dan penemuan yang pada 
hakekatnya ialah pemecahan masalah (Schmidt, Rotgans, Yew, 2011: 792_806).

Melalui penggunaan metode pembelajaran problem solving peserta didik menjadi lebih terarah dan lebih berkembang kreativitasnya dan juga mempermudah guru mata pelajaran untuk lebih mudah membimbing dan menyampaikan materi peserta didiknya. Penggunaan metode pembelajaran problem solving adalah diantara upaya untuk mengatasi kondisi peserta didik yang memerlukan suasana yang baru, sehingga pembelajaran tidak lagi membosankan. Proses ini memungkinkan peserta didik untuk mengembangkan keterampilan yang digunakan untuk latihan mereka di masa depan. Ini meningkatkan penilaian kritis, pencarian literatur dan mendorong pembelajaran berkelanjutan dalam lingkungan tim (Wood, 2003: 328-330).

Metode kooperatif Tipe Think Phair Share (TPS) yang dikembangkan oleh Spancer Kagan dan kawan-kawannya (Sadiman, 2007: 66). TPS tidak sependapat dengan asumsi bahwa setiap resitasi dan diskusi harus di-setting masing-masing kelompok dalam kelas. Dalam pembelajaran, para peserta didik dibagi ke dalam kelompok yang terdiri dari 4 sampai 6 orang peserta didik dibagi ke dalam kelompok yang terdiri dari 4 sampai 6 peserta didik yang heterogen untuk saling membantu dan bekerja sama. Penguasaan bahan pelajaran bisa diraih sangat baik, dengan catatan kepada mereka diberi waktu belajar yang cukup dan bantuan yang tepat. Pemikiran dasar mengenai pembelajaran kooperatif tipe Think Pair Share ialah pembelajaran yang memberi waktu kepada siswa untuk lebih banyak berfikir, menjawab permasalahan.

Diantara pembelajaran yang tepat dan selaras dengan karakteristik Ilmu Pengetahuan Sosial (IPS) serta bisa meningkatkan prestasi belajar peserta didik ialah melalui pembelajaran kooperatif Tipe Think Phair Share. Akan tetapi lazimnya pelaksanaan aktivitas pembelajaran terutama di Sekolah Dasar (SD) ataupun Sekolah Dasar Islam Terpadu (SDIT) mayoritas guru masih memakai metode mengajar yang berkisar pada ekspositori atau ceramah. Pelaksanaan 
pembelajaran IPS yang terfokus pada proses transfer dari guru ke peserta didik adalah pandangan behavioris (Sutawidjaja, 2007: 1). Hal ini berakibat kurang baik pada prestasi belajarnya.

Banyak faktor yang bisa mengakibatkan prestasi belajar peserta didik rendah. Diantara faktor ini ialah model pembelajaran. Pemakaian model pembelajaran yang benar bisa memotivasi tumbuhnya rasa senang peserta didik terhadap pelajaran, menumbuhkan dan menaikkan motivasi dalam mengerjakan tugas, memberi kemudahan untuk peserta didik untuk memahami pelajaran sehingga memungkinkan peserta didik mencapai hasil belajar yang lebih baik. Ironisnya, guru acapkali memakai model pembelajaran konvensional atau metode ceramah yang memiliki karakter berpusat pada guru (teacher centered), sehingga peserta didik tidak maksimal dan kurang aktif menggunakan dan mengembangkan potensinya. Aktivitas pembelajaran hanya sekedar mendengar, mendapatkan dan menyerap materi yang diajarkan oleh guru, sehingga prestasi hasil belajar tidak optimal.

Penelitian Umam dan kawan kawan menunjukkan bahwa model Pembelajaran Kooperatif Think Pair Share yang dibantu dengan TIK memiliki dampak positif pada kemampuan pemecahan masalah matematika siswa; ada perbedaan rata-rata yang signifikan secara statistik dalam kemampuan pemecahan masalah matematika siswa antara kelas eksperimen dan kelas kontrol (2017: 94-97). Metode pemecahan masalah dapat digunakan untuk meningkatkan pengetahuan konten sambil secara bersamaan membantu perkembangan komunikasi, pemecahan masalah, pemikiran kritis, kolaborasi, dan keterampilan belajar mandiri (Wells, Warelow, Jackson, 2009: 191-201; Barrett, 2010: 165-174).

Berdasarkan penelitian pendahuluan di SDIT Sabilul Huda Cirebon, prestasi belajar peserta didik pada mata pelajaran IPS kurang optimal yang terlihat dari nilai rata-rata formatif test yang di bawah KKM 7,5. Nilai rata-rata yang dimaksud adalah 5,5. Hal ini dikarenakan kurang kreatifnya guru dalam proses pembelajaran. Guru sekedar menggunakan metode konvensional 
ceramah. Dalam penelitian ini, kajian diarahkan pada pengungkapan pengaruh penggunaan metode pembelajaran problem solving dan pembelajaran kooperatif tipe Think Pair Share (TPS) terhadap prestasi peserta didik di SDIT Sabilul Huda Cirebon.

\section{B. KAJIAN TEORI}

Pembelajaran melalui problem solving ditujukan agar peserta didik bisa menggunakan rasio semaksimal mungkin sehingga ia terlatih untuk senantiasa berpikir (Armei, 2002: 101). Pembelajaran ini menghadapkan siswa pada persoalan sebagai suatu konteks untuk belajar mengenai cara berpikir kritis, keterampilan permasalahan, dan untuk mendapatkan konsep dan pengetahuan esensial dari materi pembelajaran (Mulyasa, 2004: 111). Pembelajaran ini melandaskan kepada pembelajaran konstruktivis kooperatif yang muncul dari konsep bahwa peserta didik akan lebih mudah memahami dan menemukan konsep yang sukar apabila mereka saling berdiskusi dengan temannya. Peserta didik saling membantu memecahkan permasalahan yang kompleks melalui kerjasama kelompok.

Prestasi belajar ialah hasil pengukuran dari penilaian (evaluasi) upaya belajar yang dinyatakan dalam bentuk huruf, simbol, ataupun kalimat yang menggambarkan hasil yang telah diraih oleh siswa pada periode tertentu (Suryabrata, 2006: 6).

Strategi berpikir berpasangan berbagi atau think pair share (TPS) ialah jenis pembelajaran kooperatif yang didesain untuk mempengaruhi pola interaksi peserta didik. Teknik ini memberikan peserta didik kesempatan untuk bekerjasama dengan orang lain (Asma, 2006: 11).

\section{METODE}

Pendekatan yang digunakan dalam penelitian ini adalah pendekatan kuantitatif asosiatif, yaitu penelitian yang bertujuan untuk mengetahui hubungan antara dua variabel atau lebih. Dengan penelitian ini maka akan dapat dibangun suatu teori yang dapat berfungsi untuk menjelaskan, meramalkan, dan mengontrol suatu gejala (Tanzeh dan Suyitno, 2006: 45). 
Populasi jumlah peserta didik sejumlah 350 di SDIT Sabilul Huda pada kelas VI, maka sampling yang dipakai ialah cluster sampling, sehingga diperoleh 3 kelas sejumlah total 77 siswa. Teknik pengujian ini yang akan diuji adalah validitas konstruksi dengan mengunakan uji analisis faktor dengan cara mengkorelasikan jumlah skor faktor dengan skor total. Uji instrumen kali ini dinyatakan valid jika $\mathrm{r}>0,320$ dengan $\mathrm{N}=38$ (Sugiyono, 2009: 369). Mengunakan rumus korelasi Product Moment yang dibantu dengan komputer seri program statistik SPSS versi 24. Instrumen penelitian menggunakan tes dan dokumentasi.

Teknik analisis data, tahap pertama adalah pengolahan data: editing, coding, tabulasi, penerapan data sesuai dengan pendekatan penelitian. Tahap kedua adalah analisis data, yaitu melalui tahap deskripsi data, tahap pengujian persyaratan; (a) uji Normalitas, (b) uji Multikolinieritas, (c) uji Heteroskedastisitas, (d) Autokorelasi, (e) uji Validitas, (f) uji Reliabilitas, (g) Regresi Ganda. Pengujian Hipotesis uji statistik yang akan digunakan adalah Uji T dan Uji F.

\section{HASIL DAN PEMBAHASAN}

1. Hasil Penelitian

a. Metode Pembelajaran problem solving

Alat pengumpulan data yang dipakai untuk mengukur metode pembelajaran problem solving adalah questionares yang memuat 15 butir pernyataan, yang setiap butir pernyataan memiliki 5 pilihan jawaban dengan rentang skor 1 sampai 5. Skor harapan terbawah ialah 15 dan total skor harapan tertinggi ialah 75. Berpijak kepada total skor harapan itu bisa ditetapkan interval skor setiap kelas atau jenjang yang mendiskripsikan metode pembelajaran problem solving yang memuat empat tingkatan, yakni memiliki katagori level yang sangat baik, baik, cukup dan kurang.

Berdasarkan data metode pembelajaran problem solving yang diperoleh dari responden sejumlah 77 secara kuantitatif memperlihatkan bahwa skor minimal yang diperoleh ialah 15 dan skor total maksimalnya 
ialah 75. Rentang jumlah skor maksimal yang mungkin didapatkan ialah 75 - $15=60$. Interval kelas sejumlah empat, maka lebar kelas intervalnya ialah $60: 4=15$.

Data hasil instrumen questionares metode pembelajaran problem solving dapat dilihat dalam tabel yaitu:

Tabel 1. Gambaran Metode Pembelajaran Problem Solving

\begin{tabular}{|l|l|c|c|c|}
\hline No & Interval & Kriteria & Jumlah & $\begin{array}{c}\text { Prosentase } \\
\%\end{array}$ \\
\hline 1. & Sangat Baik & $61-75$ & 51 & $66 \%$ \\
\hline 2. & Baik & $46-60$ & 26 & $44 \%$ \\
\hline 3. & Cukup & $31-45$ & 0 & $0 \%$ \\
\hline 4. & Kurang & $15-30$ & 0 & $0 \%$ \\
\hline \multicolumn{2}{|l|}{ Total } & 77 & 100 \\
\hline
\end{tabular}

Sumber Data: Pengolahan Data Metode Pembelajaran Problem Solving, 2018

Berdasarkan data dari tabel tersebut memperlihatkan bahwa 51 atau 66 $\%$ responden mempunyai metode pembelajaran problem solving dengan katagori sangat baik. Sementara itu, sejumlah 26 atau $44 \%$ responden mempunyai metode pembelajaran problem solving dengan katagori baik. Oleh karena itu, bisa dikatagorikan bahwa dari hasil studi ini memperlihatkan adanya kecenderungan metode pembelajaran problem solving dengan katagori sangat baik.

2. Pembelajaran kooperatif tipe Think Pair Share

Alat pengumpulan data yang dipakai guna mengukur pembelajaran kooperatif tipe Think Pair Share dengan menggunakan kuesioner yang mencakup 15 butir pernyataan, yang setiap butir pernyataan memiliki 5 pilihan jawaban dengan rentang skor 1 sampai 5. Skor harapan terendah ialah 15 sedangkan total skor harapan tertinggi ialah 75. Berpijak pada total skor harapan tersebut bisa ditetapkan interval skor setiap kelas atau jenjang yang mendeskripsikan pembelajaran kooperatif tipe Think Pair Share yang meliputi empat tingkatan, yakni memiliki katagori level yang sangat baik, baik, cukup dan kurang.

Data dari 77 responden tentang pembelajaran kooperatif tipe Think 
Pair Share secara kuantitatif memperlihatkan bahwa skor minimal yang diperoleh ialah 15 dan skor total maksimalnya ialah 75. Rentang jumlah skor maksimal yang mungkin didapatkan ialah $75-15=60$. Interval kelas sejumlah empat, maka lebar kelas intervalnya ialah $60: 4=15$.

Data hasil kuesioner pembelajaran kooperatif tipe Think Pair Share dapat dilihat di bawah ini:

Tabel 2 Gambaran Metode Kooperatif Tipe Think Pair Share

\begin{tabular}{|l|l|r|r|c|}
\hline No & \multicolumn{1}{|c|}{ Interval } & Kriteria & Jumlah & $\begin{array}{c}\text { Prosentase } \\
\%\end{array}$ \\
\hline 1. & Sangat Baik & $61-75$ & 47 & $61 \%$ \\
\hline 2. & Baik & $46-60$ & 30 & $39 \%$ \\
\hline 3. & Cukup & $31-45$ & 0 & $0 \%$ \\
\hline 4. & Kurang & $15-30$ & 0 & $0 \%$ \\
\hline \multicolumn{3}{|c|}{ Total } & 77 & 100 \\
\hline
\end{tabular}

Sumber Data: Pengolahan Data Metode kooperatif tipe Think Pair Share, 2018

Berdasarkan tabel tersebut memperlihatkan bahwa $61 \%$ atau 47 responden mempunyai pembelajaran kooperatif tipe Think Pair Share dengan katagori sangat baik. Sementara itu, sejumlah $39 \%$ atau 30 responden mempunyai pembelajaran kooperatif tipe Think Pair Share dengan katagori baik. Oleh karena itu, bisa dinilai bahwa dari hasil penelitian ini memperlihatkan kecenderungan pembelajaran kooperatif tipe Think Pair Share dengan katagori sangat baik.

3. Prestasi Belajar

Berpijak pada nilai tes yang sudah didapatkan bisa disajikan pada tabel di bawah ini:

Tabel 3. Distribusi Frekuensi Prestasi Belajar

\begin{tabular}{|c|l|c|r|c|}
\hline \multirow{2}{*}{ No } & \multirow{2}{*}{ Tingkat Penguasaan } & \multirow{2}{*}{ Kriteria } & \multicolumn{2}{|c|}{ Frekuensi } \\
\cline { 4 - 5 } & & & F & $\%$ \\
\hline 1. & Sangat baik & $86-100 \%$ & 11 & $14 \%$ \\
\hline 2. & Baik & $80-85 \%$ & 35 & $45 \%$ \\
\hline 3. & Cukup & $75-79 \%$ & 6 & $8 \%$ \\
\hline 4. & Kurang & $55-74 \%$ & 20 & $26 \%$ \\
\hline 5. & Sangat Kurang & $\leq 54 \%$ & 5 & $7 \%$ \\
\hline & Jumlah & & 77 & 100 \\
\hline
\end{tabular}


Sumber: Input Data Peneliti, 2018

Berpijak pada tabel tersebut, dapat ditemukan bahwa dari 77 responden, $14 \%$ responden atau 11 responden prestasi belajar peserta didik dengan tingkat penguasaan sangat baik, sebanyak 35 responden atau $45 \%$ prestasi hasil belajar peserta didik dengan tingkat penguasaan baik, sejumlah $8 \%$ atau 6 responden prestasi belajar peserta didik dengan tingkat penguasaan cukup dan sejumlah $26 \%$ atau 20 responden prestasi belajar peserta didik dengan tingkat penguasaan kurang dan hanya sebanyak $7 \%$ atau 5 responden prestasi belajar peserta didik dengan tingkat penguasaan sangat kurang. Dengan demikian, bisa disimpulkan bahwa prestasi belajar mata pelajaran IPS, pada peserta didik Kelas VI di SDIT Sabilul Huda Kota Cirebon Tahun Pelajaran 2017/2018 dengan kecenderungan prestasi belajarnya pada tingkat penguasaan kurang.

2. Pembahasan

a. Analisis Data

Pengujian validitas dalam penelitian ini memakai program SPSS versi 24.0. Sedangkan hasil pengujiannya bisa dilihat di bawah ini:

Tabel 4. Hasil Uji Validitas Instrumen Metode Pembelajaran Problem Solving

\begin{tabular}{|c|c|c|c|c|}
\hline No & Instrumen & $\begin{array}{c}\text { Pearson } \\
\text { Correlation }\end{array}$ & $\begin{array}{c}\text { R Tabel }(\mathrm{N}=25), \\
\text { Taraf Signifikasi 5\% }\end{array}$ & Keterangan \\
\hline 1 & Butir 1 & 0.455 & 0,396 & Valid \\
\hline 2 & Butir 2 & 0.739 & 0,396 & Valid \\
\hline 3 & Butir 3 & 0.558 & 0,396 & Valid \\
\hline 4 & Butir 4 & 0.702 & 0,396 & Valid \\
\hline 5 & Butir 5 & 0.557 & 0,396 & Valid \\
\hline 6 & Butir 6 & 0.748 & 0,396 & Valid \\
\hline 7 & Butir 7 & 0.738 & 0,396 & Valid \\
\hline 8 & Butir 8 & 0.718 & 0,396 & Valid \\
\hline 9 & Butir 9 & 0.676 & 0,396 & Valid \\
\hline 10 & Butir 10 & 0.518 & 0,396 & Valid \\
\hline 11 & Butir 11 & 0.591 & 0,396 & Valid \\
\hline 12 & Butir 12 & 0.700 & 0,396 & Valid \\
\hline 13 & Butir 13 & 0.631 & 0,396 & Valid \\
\hline 14 & Butir 14 & 0.882 & 0,396 & Valid \\
\hline 15 & Butir 15 & 0.856 & 0,396 & Valid \\
\hline
\end{tabular}

Sumber Data: diolah oleh peneliti, 2018 
Tabel 5. Hasil Uji Validitas Instrumen Pembelajaran Kooperatif tipe Think Pair Share

\begin{tabular}{|c|c|c|c|c|}
\hline No & Instrument & $\begin{array}{c}\text { Pearson } \\
\text { Correlation }\end{array}$ & $\begin{array}{c}\text { R Tabel (N } \\
\text { 25), Taraf } \\
\text { Signifikasi 5 \% }\end{array}$ & Keterangan \\
\hline 1 & Butir 1 & 0.682 & 0,396 & Valid \\
\hline 2 & Butir 2 & 0.704 & 0,396 & Valid \\
\hline 3 & Butir 3 & 0.617 & 0,396 & Valid \\
\hline 4 & Butir 4 & 0.409 & 0,396 & Valid \\
\hline 5 & Butir 5 & 0.704 & 0,396 & Valid \\
\hline 6 & Butir 6 & 0.768 & 0,396 & Valid \\
\hline 7 & Butir 7 & 0.680 & 0,396 & Valid \\
\hline 8 & Butir 8 & 0.680 & 0,396 & Valid \\
\hline 9 & Butir 9 & 0.782 & 0,396 & Valid \\
\hline 10 & Butir 10 & 0.554 & 0,396 & Valid \\
\hline 11 & Butir 11 & 0.619 & 0,396 & Valid \\
\hline 12 & Butir 12 & 0.778 & 0,396 & Valid \\
\hline 13 & Butir 13 & 0.683 & 0,396 & Valid \\
\hline 14 & Butir 14 & 0.858 & 0,396 & Valid \\
\hline 15 & Butir 15 & 0.802 & 0,396 & Valid \\
\hline
\end{tabular}

Sumber Data: Peneliti, 2015

Tabel 6. Hasil Uji Validitas Prestasi Belajar

\begin{tabular}{|c|c|c|c|c|}
\hline No & Instrumen & $\begin{array}{c}\text { Pearson } \\
\text { Correlation }\end{array}$ & $\begin{array}{c}\text { R Tabel (N= } \\
\text { 25), Taraf } \\
\text { Signifikasi 5 } \\
\%\end{array}$ & Keterangan \\
\hline 1 & Soal 1 & 0.740 & 0,396 & Valid \\
\hline 2 & Soal 2 & 0.762 & 0,396 & Valid \\
\hline 3 & Soal 3 & 0.664 & 0,396 & Valid \\
\hline 4 & Soal 4 & 0.725 & 0,396 & Valid \\
\hline 5 & Soal 5 & 0.711 & 0,396 & Valid \\
\hline 6 & Soal 6 & 0.794 & 0,396 & Valid \\
\hline 7 & Soal 7 & 0.711 & 0,396 & Valid \\
\hline 8 & Soal 8 & 0.806 & 0,396 & Valid \\
\hline 9 & Soal 9 & 0.711 & 0,396 & Valid \\
\hline 10 & Soal 10 & 0.806 & 0,396 & Valid \\
\hline
\end{tabular}

Sumber Data: diolah Peneliti, 2018

Uji reliabilitas dipakai untuk mengetahui apakah indikator yang dipakai bisa dipercaya sebagai instrumen ukur variabel, indikator dinyatakan reliabel jika nilai cronbach's alpha $(\alpha)$ yang diperoleh $\geq 0,60$. 
Hasil uji reliabilitas yang dilakukan dengan memakai program SPSS versi 24.0 bisa disajikan yaitu:

Tabel 7. Hasil Uji Reliabilitas

\begin{tabular}{|l|c|c|c|}
\hline \multicolumn{1}{|c|}{ Variabel } & $\begin{array}{c}\text { Cronbach's } \\
\text { Alpha }\end{array}$ & $\begin{array}{c}\text { Standar } \\
\text { Reliabilitas }\end{array}$ & Keterangan \\
\hline $\begin{array}{l}\text { metode pembelajaran problem } \\
\text { solving }\left(\mathrm{X}_{1}\right)\end{array}$ & 0,912 & 0,60 & Reliable \\
\hline $\begin{array}{l}\text { Pembelajaran kooperatif tipe } \\
\text { Think Pair Share }\left(\mathrm{X}_{2}\right)\end{array}$ & 0,918 & 0,60 & Reliable \\
\hline prestasi belajar (Y) & 0,902 & 0,60 & Reliable \\
\hline
\end{tabular}

Sumber Data: Diolah peneliti, 2018

Berpijak pada data tersebut diketahui bahwa hasil nilai cronbach's alpha $(\alpha)$ variabel $\mathrm{X}_{1}, \mathrm{X}_{2}$ dan $\mathrm{Y}>0,60$ sehingga angket dari ketiga variabel tersebut dapat dipercaya atau reliabel sebagai instrumen ukur variabel. Dalam bagian ini ada dua pengujian asumsi dasar yang mencakup pengujian normalitas, pengujian multikolinieritas, heteroskesdastisitas, pengujian heteroskesdastisitas, autokorelasi.

1) Normalitas

Pengujian normalitas ini ditujukan untuk mengungkap normal tidaknya data yang didapatkan. Diantara cara untuk mengecek normalitas ialah dengan berlandaskan pada hasil tabel uji normalitas diketahui bahwa nilai signifikansi variabel prestasi belajar ialah 0,002 dan nilai signifikansi variabel metode problem solving ialah 0,000, nilai signifikansi variabel pembelajaran TPS ialah 0,185 , sebab nilai prestasi belajar dan metode problem solving $<0,05$ bermakna distribusi tidak normal, sedangkan variabel pembelajaran kooperatif tipe Think Pair Share ialah $>0,05$ ini bermakna distribusi normal, sebagaimana dapat dilihat hasil uji normalitas, yaitu:

Tabel 8. Hasil Pengujian Normalitas

Tests of Normality

\begin{tabular}{|l|r|r|r|r|r|r|}
\hline & \multicolumn{3}{|c|}{ Kolmogorov-Smirnov(a) } & \multicolumn{3}{c|}{ Shapiro-Wilk } \\
\cline { 2 - 7 } & Statistic & \multicolumn{1}{c|}{ df } & \multicolumn{1}{c|}{ Sig. } & \multicolumn{1}{c|}{ Statistic } & \multicolumn{1}{c|}{ df } & \multicolumn{1}{c|}{ Sig. } \\
\hline Prestasi_Belajar_Y & .132 & 77 & .002 & .948 & 77 & .004 \\
Metode_Problem_S & .156 & 77 & .000 & .935 & 77 & .001 \\
olving_X1 & & & & & &
\end{tabular}




\begin{tabular}{|l|l|l|l|l|l|l|}
$\begin{array}{l}\text { Pembelajaran_TPS_ } \\
\text { X2 }\end{array}$ & .090 & 77 & .185 & .952 & 77 & .005 \\
\hline
\end{tabular}

a Lilliefors Significance Correction

2) Pengujian Multikolieritas

Pengujian asumsi dasar ini digunakan untuk analisis regresi yang meliputi dua atau lebih variabel dimana akan diukur level keeratan (asosiasi) pengaruh atau hubungan antar variabel dengan besaran koefisien korelasi (r). Disebut multikolieritas apabila koefisien korelasi antar variabel bebas (X) kurang dari 5. Dipandang tidak terjadi multikolinieritas apabila koefisien korelasi antar variabel bebas lebih kecil ataupun sama dengan 5. Penelitian ini memperlihatkan koefisien korelasi antar variabel yakni $1.001<$ dari 5, artinya terjadi multikolieritas. Hasil pengujian multikolieritas dapat disajikan, yaitu:

Tabel 9 Pengujian Multikolieritas

Coefficients(a)

\begin{tabular}{|c|c|c|c|c|c|c|c|c|}
\hline \multirow[t]{2}{*}{$\begin{array}{l}\text { Mod } \\
\text { el }\end{array}$} & & \multicolumn{2}{|c|}{$\begin{array}{l}\text { Unstandardize } \\
\text { d Coefficients }\end{array}$} & \multirow{2}{*}{$\begin{array}{c}\text { Standard } \\
\text { ized } \\
\text { Coefficie } \\
\text { nts }\end{array}$} & \multirow[b]{2}{*}{$\mathrm{t}$} & \multirow[b]{2}{*}{ Sig. } & \multicolumn{2}{|c|}{$\begin{array}{l}\text { Collinearity } \\
\text { Statistics }\end{array}$} \\
\hline & & $\mathrm{B}$ & $\begin{array}{l}\text { Std. } \\
\text { Error }\end{array}$ & & & & $\begin{array}{c}\text { Tolera } \\
\text { nce }\end{array}$ & VIF \\
\hline 1 & (Constant) & 74.906 & $\begin{array}{r}33.1 \\
51\end{array}$ & & 2.260 & .027 & & \\
\hline & $\begin{array}{l}\text { Metode_Proble } \\
\text { m_Solving_X1 }\end{array}$ & .739 & .358 & .224 & 2.062 & .043 & 999 & $\begin{array}{r}1.00 \\
1\end{array}$ \\
\hline & $\begin{array}{l}\text { Pembelajaran_ } \\
\text { TPS_X2 }\end{array}$ & .773 & .315 & .267 & 2.453 & .017 & 999 & $\begin{array}{r}1.00 \\
1\end{array}$ \\
\hline
\end{tabular}

a Dependent Variable: Prestasi_Belajar_Y

Berdasarkan output Coeffisients tersebut, terlihat pada kolom VIF bisa diketahui bahwa nilai VIF bagi metode pembelajaran problem solving dan pembelajaran kooperatif tipe Think Pair Share memperlihatkan VIF adalah kurang dari 5, maka bisa ditarik kesimpulan bahwa model regresi tidak ditemukan adanya multikolinieritas. 


\section{3) Pengujian Heteroskedastisitas}

Heteroskedastisitas muncul apabila pada scatterplot titik-titik hasil pengolahan data antara ZPRED dan SREID menyebar di bawah ataupun di atas titik origin (angka 0 ) pada sumbu Y dan tidak memiliki pola yang teratur. Heteroskedastisitas terjadi apabila pada scatterplot titik-titiknya memiliki pola yang teratur baik bergelombang-gelombang, melebar, maupun menyempit.

Dalam penelitian berpijak kepada hasil output SPSS 24.00 gambar scatterplot diperoleh ini scatterplot titik-titiknya menyebar di bawah dan di atas sumbu $\mathrm{Y}$ dan tidak memiliki pola yang teratur, sehingga bisa ditarik kesimpulan bahwa gambar tersebut memperlihatkan tidak adanya heteroskesdastisitas.

4) Uji Autokorelasi

Untuk menguji autokorelasi memakai hasil uji Durbin Watson. Hasil pengujian Durbin Watson bisa yaitu:

Tabel 10 Hasil Pengujian Autokorelasi

Model Summary ${ }^{\mathrm{b}}$
\begin{tabular}{|l|c|c|c|c|c|}
\hline Model & $\mathrm{R}$ & R Square & $\begin{array}{c}\text { Adjusted } \\
\text { R Square }\end{array}$ & $\begin{array}{c}\text { Std. Error of } \\
\text { the Estimate }\end{array}$ & $\begin{array}{c}\text { Durbin- } \\
\text { Watson }\end{array}$ \\
\hline 1 & $.322^{\mathrm{a}}$ & .104 & .079 & 12.271 & 1.557 \\
\hline
\end{tabular}
a. Predictors: (Constant), $\times 2, \times 1$
b. Dependent Variable: prestasi_Belajar_Y

Dari output tersebut diperoleh nilai Durbin Watson yang didapatkan dari model regresi ialah 1.557 terletak diantara $\mathrm{DW} \pm 2$. Dengan demikian, maka dapat ditarik kesimpulan, data tersebut tidak adanya autokorelasi positif dan data yang baik ialah data yang tidak ada autokorelasi.

b. Uji Hipotesis

1) Analisis Determinasi (R2)

Analisis korelasi yang didapatkan dari output regresi, yaitu:

Tabel 11. Hasil Koefisien Diterminasi 
Model Summary

\begin{tabular}{|l|c|c|c|c|}
\hline Model & $\mathrm{R}$ & R Square & $\begin{array}{c}\text { Adjusted R } \\
\text { Square }\end{array}$ & $\begin{array}{c}\text { Std. Error of the } \\
\text { Estimate }\end{array}$ \\
\hline 1 & $.353(\mathrm{a})$ & .125 & .101 & 12.125 \\
\hline
\end{tabular}

a Predictors: (Constant), Pembelajaran_TPS_X Metode_Problem_Solving_X1

Hasil analisis korelasi ganda bisa ditinjau dalam output Model Summary dari hasil analisis regresi linier berganda tersebut. Berpijak pada output didapatkan angka $\mathrm{R}$ sebesar 0,353. Maka bisa ditarik kesimpulan bahwa 35,3\% adanya korelasi yang rendah antara metode pembelajaran problem solving dan pembelajaran kooperatif tipe Think Pair Share terhadap prestasi belajar IPS. Sementara sisanya dipengaruhi oleh variabel dari luar penelitian.

Guna menghitung sejauhmana pengaruh metode pembelajaran problem solving dan pembelajaran kooperatif tipe Think Pair Share terhadap prestasi belajar IPS dengan memakai angka angka korelasi yang dikuadratkan ( $R$ Square). Angka $R$ Square dinamakan juga KD (Koefisiensi Determinasi). Besarnya angka Koefisiensi Diterminasi pada perhitungan itu adalah sebesar 0,125 atau sama dengan 12,5\% (Rumus untuk menghitung Koefisiensi Determinasi adalah $\mathrm{r}^{2}$ x 100\%). Angka itu memiliki makna bahwa, besarnya pengaruh metode pembelajaran problem solving dan pembelajaran kooperatif tipe Think Pair Share (TPS) terhadap prestasi belajar IPS ialah $12,5 \%$, sementara sisanya yakni mesti diuraikan oleh faktor-faktor penyebab lainnya yang berasal dari luar regresi.

2) $\mathrm{Uji} \mathrm{t}$

a) Ditetapkan Hipotesis $\mathrm{H}_{\mathrm{o}}$ dan $\mathrm{H}_{\mathrm{a}}$

$\mathrm{H}_{\mathrm{a}}$ Terdapat pengaruh metode pembelajaran problem solving terhadap prestasi belajar IPS di SDIT Sabilul Huda Cirebon.

$\mathrm{H}_{\mathrm{o}} \quad$ Tidak terdapat pengaruh metode pembelajaran problem solving terhadap prestasi belajar IPS di SDIT Sabilul Huda Cirebon.

$\mathrm{H}_{\mathrm{a}}$ Terdapat pengaruh Pembelajaran kooperatif tipe Think Pair Share 
terhadap prestasi belajar IPS di SDIT Sabilul Huda Cirebon.

$\mathrm{H}_{\mathrm{o}}$ Tidak terdapat pengaruh Pembelajaran kooperatif tipe Think Pair Share terhadap prestasi belajar IPS di SDIT Sabilul Huda Cirebon.

b) Merumuskan taraf signifikansi

Nilai signifikansi $>\alpha(0,05)$, maka $\mathrm{H}_{\mathrm{o}}$ diterima dan $\mathrm{H}_{\mathrm{a}}$ ditolak $\left(\mathrm{t}_{\text {hitung }}>\mathrm{t}_{\text {tabel }}\right)$, sedangkan jika nilai signifikansi $<\alpha(0,05)$, maka $\mathrm{H}_{\mathrm{o}}$ ditolak dan $\mathrm{H}_{\mathrm{a}}$ diterima.

(1) Pengujian hipotesis secara parsial (uji t)

Untuk menguji pengaruh metode pembelajaran problem solving dan pembelajaran kooperatif tipe Think Pair Share terhadap prestasi belajar IPS di SDIT Sabilul Huda signifikan atau tidak, dalam studi ini memakai perbandingan $t_{\text {hitung }}$ dan $t_{\text {tabel }}$ pada taraf signifikan $5 \%$ dan N 77. Sementara itu tabel distribusi t dicapai pada $\alpha=5 \%: 2=2,5 \%$ (uji 2 sisi) dengan derajat kebebasan (df) $n$ - $\mathrm{k}-1=77-3-1=74$ ( $\mathrm{n}$ ialah jumlah responden dan $\mathrm{k}$ ialah jumlah variabel independen). Hasil didapatkan dari t tabel yaitu 1.993. Dalam pengujian ini menggunakan program SPSS 24.0 for Windows didapatkan hasil yaitu:

Tabel 12. Coefficients(a)

\begin{tabular}{|l|l|r|r|r|r|r|}
\hline $\begin{array}{l}\text { Mod } \\
\text { el }\end{array}$ & & \multicolumn{2}{|c|}{$\begin{array}{c}\text { Unstandardized } \\
\text { Coefficients }\end{array}$} & $\begin{array}{c}\text { Standardized } \\
\text { Coefficients }\end{array}$ & \multicolumn{1}{c|}{$\mathrm{t}$} & \multicolumn{1}{c|}{ Sig. } \\
\hline & & \multicolumn{1}{c|}{ B } & \multicolumn{1}{c|}{$\begin{array}{c}\text { Std. } \\
\text { Error }\end{array}$} & \multicolumn{1}{c|}{ Beta } & & \\
\hline 1 & (Constant) & 74.906 & 33.151 & & 2.260 & .027 \\
& Metode_Problem_Solvi & .739 & .358 & .224 & 2.062 & .043 \\
& ng_X1 & .773 & .315 & .267 & 2.453 & .017 \\
\hline
\end{tabular}

a Dependent Variable: Prestasi_Belajar_Y

Berdasarkan hasil pada tabel tersebut bisa terungkap bahwa pengujian hipotesis alternatif $\left(\mathrm{H}_{\mathrm{a}}\right)$ pertama diterima. Pengujian hipotesis pertama dilakukan melalui perbandingan antara hasil dari $\mathrm{t}_{\text {hitung }}$ dengan $\mathrm{t}_{\text {tabel}}$. Berdasarkan tabel Coefficients di atas didapatkan nilai $t_{\text {hitung }}=$ 2.062. Sedangkan, untuk $t_{\text {tabel }}$ dengan taraf 
signifikakansi 0,05 didapatkan nilai $t_{\text {tabel }}=1,993$. Perbandingan antara keduanya menghasilkan: $t_{\text {hitung }}>t_{\text {tabel }}(2.062>1,993)$. Nilai signifikansi t untuk variabel metode problem solving ialah 0.043 dan nilai tersebut lebih kecil daripada probabilitas $0.05(0,043<0,05)$. Dengan demikian dalam pengujian ini memperlihatkan bahwa $\mathrm{H}_{\mathrm{a}}$ diterima dan $\mathrm{H}_{\mathrm{o}}$ ditolak. Hal itu bermakna bahwa terdapat pengaruh yang signifikan metode pembelajaran problem solving terhadap prestasi belajar IPS di SDIT Sabilul Huda Cirebon.

Hasil pengujian hipotesis alternatif $\left(\mathrm{H}_{\mathrm{a}}\right)$ kedua diterima. Berpijak pada tabel Coefficients di atas juga, untuk pengujian hipotesis kedua dengan menggunakan uji t. Pengujian hipotesis kedua dilakukan dengan cara mengkomparasikan antara hasil dari $\mathrm{t}_{\text {hitung }}$ dengan $\mathrm{t}_{\text {tabel. }}$. Dari tabel Coefficients di atas didapatkan nilai $\mathrm{t}_{\text {hitung }}=2$ 2.453. Sedangkan, untuk $\mathrm{t}_{\text {tabel }}$ dengan taraf signifikakansi 0,05 , didapatkan nilai $t_{\text {tabel }}=1,993$. Perbandingan antara keduanya menghasilkan: $t_{\text {hitung }}>t_{\text {tabel }}(2.453>1,993)$. Nilai signifikansi $t$ untuk variabel pembelajaran kooperatif tipe Think Pair Share ialah 0.017 dan nilai tersebut lebih kecil daripada probabilitas $0,05(0,017<$ 0,05). Dengan demikian, dalam pengujian ini memperlihatkan bahwa $\mathrm{H}_{\mathrm{a}}$ diterima dan $\mathrm{H}_{\mathrm{o}}$ ditolak. Itu artinya bahwa ada pengaruh yang signifikan pembelajaran kooperatif tipe Think Pair Share terhadap prestasi belajar IPS di SDIT Sabilul Huda Cirebon.

Hasil penghitungan uji hipotesis yang dimaksud bisa dilihat pada tabel di bawah ini.

Tabel 13 Hasil Uji Hipotesis

\begin{tabular}{|c|c|c|c|c|c|}
\hline No & $\begin{array}{l}\text { Hipotesis Nol }\left(\mathrm{H}_{\mathrm{o}}\right) \text { dan Hipotesis } \\
\text { alternatif }\left(\mathrm{H}_{\mathrm{a}}\right)\end{array}$ & $\begin{array}{c}\mathrm{t} \\
\text { hitung }\end{array}$ & $\begin{array}{c}\mathrm{t} \\
\text { tabel }\end{array}$ & $\begin{array}{c}\text { Hasil } \\
\text { Signifikansi }\end{array}$ & $\begin{array}{l}\text { Kesimpu } \\
\text { lan }\end{array}$ \\
\hline 1. & $\begin{aligned} \mathrm{H}_{\mathrm{a}}: & \text { Terdapat pengaruh metode } \\
& \text { pembelajaran problem solving } \\
& \text { terhadap prestasi belajar IPS di } \\
& \text { SDIT Sabilul Huda Cirebon. } \\
\mathrm{H}_{\mathrm{o}}: & \text { Tidak terdapat pengaruh metode }\end{aligned}$ & 2.062 & 1.993 & $\begin{array}{l}2.062> \\
1,993 \\
\alpha=0,05 \\
\operatorname{sig}=0,043\end{array}$ & $\begin{array}{l}\mathrm{H}_{\mathrm{a}} \\
\text { diterima } \\
\mathrm{H}_{\mathrm{o}} \\
\text { ditolak }\end{array}$ \\
\hline
\end{tabular}




\begin{tabular}{|c|c|c|c|c|c|}
\hline & $\begin{array}{l}\text { pembelajaran problem solving } \\
\text { terhadap prestasi belajar IPS di } \\
\text { SDIT Sabilul Huda Cirebon. }\end{array}$ & & & & \\
\hline 2. & $\begin{aligned} \mathrm{H}_{\mathrm{a}}: & \text { Terdapat pengaruh pembelajaran } \\
& \text { kooperatif tipe Think Pair Share } \\
& \text { terhadap prestasi belajar IPS di } \\
& \text { SDIT Sabilul Huda Cirebon. } \\
\mathrm{H}_{\mathrm{o}}: & \text { Tidak terdapat pengaruh } \\
& \text { pembelajaran kooperatif tipe } \\
& \text { Think Pair Share terhadap } \\
& \text { prestasi belajar IPS di SDIT } \\
& \text { Sabilul Huda Cirebon. }\end{aligned}$ & 2.453 & 1.993 & $\begin{array}{l}2.453>1,993 \\
\alpha=0,05 \\
\operatorname{sig}=0,017\end{array}$ & $\begin{array}{l}\mathrm{H}_{\mathrm{a}} \\
\text { diterima } \\
\mathrm{H}_{\mathrm{o}} \\
\text { ditolak }\end{array}$ \\
\hline
\end{tabular}

(2) Uji F

Uji $\mathrm{F}$ ditujukan guna mengetahui pengaruh masing-masing variabel $X_{1}, X_{2}$ dan $X_{3}$ terhadap variabel $Y$. Dalam hal ini ialah metode pembelajaran problem solving dan pembelajaran kooperatif tipe Think Pair Share terhadap prestasi belajar IPS di SDIT Sabilul Huda Cirebon dengan memakai perbandingan $\mathrm{F}$ hitung dan $\mathrm{F}$ tabel dengan taraf signifikansi $5 \%$ dan $\mathrm{N} 77$, didapatkan $\mathrm{F}_{\text {tabel }}$ ialah 3.115 dengan memakai tingkat keyakinan $95 \%, \alpha=5 \%$, df 3 (jumlah variabel -1$)$ atau $3-1=2$, dan df $2(n-k-1)$ atau $77-3-1=74(n$ jumlah responden dan $\mathrm{k}$ ialah jumlah variabel bebas). Hasil didapatkan dari $\mathrm{F}$ tabel ialah 3,115. Berpijak pada perhitungan dengan menggunakan program SPSS versi 24.00 didapatkan hasil, yaitu:

Tabel 14. Hasil Anova

ANOVA (b)

\begin{tabular}{|c|c|c|c|c|c|c|}
\hline Model & & $\begin{array}{l}\text { Sum of } \\
\text { Squares }\end{array}$ & $\mathrm{df}$ & $\begin{array}{l}\text { Mean } \\
\text { Square }\end{array}$ & $F$ & Sig. \\
\hline \multirow[t]{3}{*}{1} & Regression & 1550.427 & 2 & 775.214 & \multirow[t]{3}{*}{5.273} & \multirow[t]{3}{*}{$.007(a)$} \\
\hline & Residual & $\begin{array}{r}10878.79 \\
4\end{array}$ & 74 & 147.011 & & \\
\hline & Total & $\begin{array}{r}12429.22 \\
1\end{array}$ & 76 & & & \\
\hline
\end{tabular}

a Predictors: (Constant), Pembelajaran_TPS_X2, Metode_Problem_Solving_X1

b Dependent Variable: Prestasi_Belajar_Y 
Berdasarkan tabel tersebut dengan hasil analisis data memakai perhitungan SPSS versi 24.00 didapatkan F hitung yaitu 5.273. Hal ini memperlihatkan $\mathrm{F}$ hitung (5.273) $>\mathrm{F}$ tabel (3.115) dan tingkat signifikansi $0,007<0,05$. Hasil pengujian memperlihatkan bahwa nilai signifikansi uji serempak (uji F) didapatkan nilai 0,010. Oleh karena itu, nilai signifikansi yang didapatkan lebih kecil daripada probabilitas $\alpha$ yang disepakati $(0,000<0,05)$. Dengan demikian, $\mathrm{H}_{\mathrm{o}}$ ditolak dan $\mathrm{H}_{\mathrm{a}}$ diterima dan bisa disimpulkan terdapat pengaruh metode pembelajaran problem solving dan pembelajaran kooperatif tipe Think Pair Share terhadap prestasi belajar IPS di SDIT Sabilul Huda Cirebon.

Sementara itu, mengenai hasil uji linier berganda bisa disajikan dalam tabel coefficients, yaitu:

Tabel 15. Hasil Analisis Regresi Linier Berganda

Coefficients(a)

\begin{tabular}{|r|l|r|r|r|r|r|}
\hline \multirow{2}{*}{ Model } & & \multicolumn{2}{|c|}{$\begin{array}{c}\text { Unstandardized } \\
\text { Coefficients }\end{array}$} & $\begin{array}{c}\text { Standardized } \\
\text { Coefficients }\end{array}$ & \multicolumn{1}{c|}{$\mathrm{t}$} & \multicolumn{1}{c|}{ Sig. } \\
\hline & & \multicolumn{1}{|c|}{ B } & Std. Error & \multicolumn{1}{c|}{ Beta } & & \\
\hline 1 & & 74.906 & 33.151 & & 2.260 & .027 \\
& $\begin{array}{l}\text { (Constant) } \\
\text { Metode_Problem_So } \\
\text { lving_X1 }\end{array}$ & .739 & .358 & .224 & 2.062 & .043 \\
& $\begin{array}{l}\text { Pembelajaran_TPS_ } \\
\text { X2 }\end{array}$ & .773 & .315 & .267 & 2.453 & .017 \\
\hline
\end{tabular}

a Dependent Variable: Prestasi_Belajar_Y

Berdasarkan tabel hasil analisis regresi, maka bisa didapatkan hasil persamaan regresi, yaitu:

$\mathrm{Y}=\mathrm{a}+\mathrm{b}_{1} \mathrm{X}_{1}+\mathrm{b}_{2} \mathrm{X}_{2}$

Prestasi belajar $(\mathrm{Y})=74.906+(0.739) \mathrm{X}_{1}+(0.773) \mathrm{X}_{2}$

Standar error persamaan regresi ialah 74.906 untuk beta $=0$, standar error persamaan regresi variabel metode problem solving, yaitu 0,358, standar error persamaan regresi variabel pembelajaran kooperatif tipe Think Pair Share ialah 0.773, standar error persamaan regresi variabel metode problem solving ialah 0.739 . Nilai signifikansi t variabel 
metode problem solving ialah 2.062, dan nilai signifikansi t variabel pembelajaran kooperatif tipe Think Pair Share ialah 2.453. Dengan demikian, bisa ditarik kesimpulan bahwa metode pembelajaran problem solving dan pembelajaran kooperatif tipe Think Pair Share secara parsial berpengaruh signifikan terhadap prestasi belajar siswa nilai signifikansi masing-masing variabel lebih kecil $(<)$ daripada nilai probabilitas yang ditentukan yakni 0,05. Maka bisa ditarik kesimpulan bahwa metode pembelajaran problem solving dan pembelajaran kooperatif tipe Think Pair Share secara parsial berpengaruh secara signifikan terhadap prestasi belajar IPS di SDIT Sabilul Huda Cirebon.

Dari persamaan regresi tersebut bisa dimaknai:

1) Nilai konstanta adalah 74.906. Hal itu memperlihatkan jika nilai metode pembelajaran problem solving $\left(\mathrm{X}_{1}\right)$, pembelajaran kooperatif tipe Think Pair Share $\left(\mathrm{X}_{2}\right)$ di obyek penelitian sama dengan nol, maka besarnya prestasi belajar siswa (Y) adalah 74.906.

2) Nilai koefisien $b_{1}$ adalah 0,739 . Hal itu memperlihatkan jika nilai metode pembelajaran problem solving $\left(\mathrm{X}_{1}\right)$ mengalami kenaikan satu poin. Sedangkan pembelajaran kooperatif tipe Think Pair Share $\left(\mathrm{X}_{2}\right)$ tetap, maka prestasi belajar siswa meningkat 0,739.

3) Nilai koefisien $b_{2}$ adalah 0.773. Hal itu memperlihatkan jika nilai pembelajaran kooperatif tipe Think Pair Share $\left(\mathrm{X}_{2}\right)$ mengalami kenaikan satu poin, sedangkan metode pembelajaran problem solving $\left(\mathrm{X}_{1}\right)$ tetap, maka prestasi belajar meningkat sejumlah 5.527.

\section{E. KESIMPULAN}

Metode pembelajaran problem solving mata pelajaran IPS mendapatkan kecenderungan $66 \%$ atau 51 responden mempunyai metode pembelajaran problem solving dengan katagori sangat baik. Pembelajaran kooperatif tipe Think Pair Share mata pelajaran IPS mendapatkan kecenderungan $61 \%$ atau 47 responden mempunyai pembelajaran kooperatif tipe Think Pair Share dengan katagori sangat baik. 
Pengaruh metode pembelajaran problem solving terhadap prestasi belajar IPS di SDIT Sabilul Huda dibuktikan dari penghitungan nilai $\mathrm{t}_{\text {hitung }}=2.062$. Sedangkan untuk $\mathrm{t}_{\text {tabel }}$ dengan taraf signifikansi 0,05 didapatkan nilai $\mathrm{t}_{\text {tabel }}=$ 1,993. Perbandingan antara keduanya menghasilkan: $\mathrm{t}_{\text {hitung }}>\mathrm{t}$ tabel $(2.062>$ 1,993). Nilai signifikansi t untuk variabel metode problem solving ialah 0.043 dan nilai tersebut lebih kecil daripada probabilitas $0.05(0,043<0,05)$. Sehingga dalam pengujian ini memperlihatkan bahwa $\mathrm{H}_{\mathrm{a}}$ diterima dan $\mathrm{H}_{\mathrm{o}}$ ditolak. Itu artinya bahwa ada pengaruh yang signifikan pengaruh metode pembelajaran problem solving terhadap prestasi belajar IPS di SDIT Sabilul Huda.

Pengaruh pembelajaran kooperatif tipe Think Pair Share terhadap prestasi belajar IPS di SDIT Sabilul Huda dibuktikan dari perhitungan $\mathrm{t}_{\text {hitung }}=$ 2.453. Sedangkan untuk $t_{\text {tabel }}$ dengan taraf signifikansi 0,05 , didapatkan nilai $t_{\text {tabel }}=1,993$. Perbandingan antara keduanya menghasilkan: $t_{\text {hitung }}>t_{\text {tabel }}(2.453$ $>1,993)$. Nilai signifikansi t untuk variabel pembelajaran kooperatif tipe Think Pair Share ialah 0.017 dan nilai tersebut lebih kecil daripada probabilitas 0,05 $(0,017<0,05)$. Sehingga dalam pengujian ini memperlihatkan bahwa $\mathrm{H}_{\mathrm{a}}$ diterima dan $\mathrm{H}_{\mathrm{o}}$ ditolak. Itu artinya bahwa ada pengaruh yang signifikan pengaruh pembelajaran kooperatif tipe Think Pair Share terhadap prestasi belajar IPS di SDIT Sabilul Huda.

Variabel penelitian yang pengaruhnya lebih besar terhadap prestasi belajar IPS di SDIT Sabilul Huda bisa ditinjau dari $t$ hitung variabel Pembelajaran kooperatif tipe Think Pair Share $(2.453>2.062)$, sehingga bisa dinyatakan bahwa pembelajaran kooperatif tipe Think Pair Share ialah memiliki pengaruh lebih besar dari pada metode pembelajaran problem solving terhadap prestasi belajar IPS di SDIT Sabilul Huda.

\section{DAFTAR PUSTAKA}

Arif, Armei. 2002. Pengantar Ilmu dan Metodelogi Pendidikan Islam. Jakarta: Ciputat Pres. 
Asaju, Kayode, Silas Felix Anyio, Thomas John Kajang, 2013.Human resource development and educational Standard in Nigeria", dalam Global Journal of Huma Social Science Linguistics and Education. Vol. 13, Issue 7, version 1.0: $1-7$.

Asma, Nur. 2006. Model Pembelajaran Kooperatif. Jakarta: Dirjen Dikti.

Barrett, Terry. 2010. "The Problem-based Learning Process as Finding and being in Flow", dalam Innovations in Education and Teaching International. 47 (2): 165-174.

Fatah, Nanang. 2004. Landasan Manajemen Pendidikan. Bandung: PT. Remaja Rosdakarya.

Fredriksson, Ulf. 2014. "Quality Education: The Key Role of Teachers," dalam Education International Working Papers no. 14. September 2004.

Mulyasa, E. 2004. Implementasi Kurikulum 2004 Panduan Pembelajaran KBK. Bandung: PT Remaja Rosdakarya.

Sadiman, Arif S., dkk, 2007. Media Pendidikan "Pengertian, Pengembangan dan Pemanfaatannya”. Jakarta: PT.Raja Grafindo Persada.

Schmidt, Henk G, Jerome I Rotgans, Elaine HJ Yew. 2011. "The Process of Problem-based Learning: What Works and Why", dalam Medical Education. 45 (8): 792-806.

Sugiyono. 2009. Statistika untuk Penelitian. Bandung: Alfabeta

Sutawidjaja, Akbar. 2007. Pembelajaran Matematika Konsturktivisme, Makalah Disajikan dalam Workshop Pembelajaran Kontemporer STAIN Tulungagung, Tulungagung 12 -14 Juli 2007.

Suryabrata, Sumadi. 2006. Psikologi Pendidikan. Jakarta: PT Raja Grafindo.

Tanzeh, Ahmad dan Suyitno. 2006. Dasar-Dasar Penelitian. Surabaya: Lembaga Kajian Agama dan Filsafat (eLKAF).

Umam, Khoerul, Suswandari, Nur Asiah, Indri Trisno Wibowo dan Syaiful Rohim, 2017. "The Effect of Think-Pair-Share Cooperative Learning Model Assisted With ICT on Mathematical Problem Solving Ability among Junior High School Students", dalam Workshop Proceedings of the 25th International Conference on Computers in Education. New Zealand: AsiaPacific Society for Computers in Education.

Wells, Samantha H; Warelow, Philip J; Jackson, Karen L 2009. "Problem based Learning (PBL): A Conundrum", dalam Contemporary Nurse. 33 (2): 191201.

Wood, D. F. 2003. “ABC of Learning and Teaching in Medicine: Problem based Learning”, dalam BMJ. 326 (7384): 328-330. 